\title{
Bioedusiana
}

Blology

Education

Department

Universitas Siliwangi

http://jurnal.unsil.ac.id/index.php/bioed

DOI: https://doi.org/10.37058/bioed.v6i2.2985

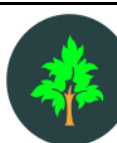

Bioedusiana

Jurnal Pendidikan Biologi

\section{Pengembangan Modul Materi Virus Terintegrasi Nilai-Nilai Islam Berbasis E-Learning dan QR Code}

\section{Development of Module Integrated Islamic Value Based on E-Learning Quizizz and QR Code Virus Materials}

\author{
Hafis M Kaunang Ataji ${ }^{1 *}$, Agus Sujarwanta ${ }^{2}$, Muhfahroyin ${ }^{3}$ \\ 1,2,3 Program Pascasarjana Pendidikan Biologi Universitas Muhammadiyah Metro Lampung, JL. KH \\ Dewantara No. 116 Iringmulyo, Kota Metro, 34111
}

\begin{abstract}
Abstrak
Pengembangan modul ini didasarkan pada pentingnya penggunaan modul bagi siswa dalam proses pembelajaran secara mandiri dan adaptasi dari proses pembelajaran saat ini yang menuntut penggunaan platform online dalam pembelajaran secara optimal. Tujuan dari penelitian ini adalah menghasilkan produk berupa pengembangan modul materi virus terintegrasi berbasis nilai-nilai Islami dalam E-Learning dan QR Code untuk SMA Kelas X yang layak digunakan oleh siswa. Dan untuk mengatasi masalah pembelajaran dengan mengembangkan bahan ajar yang lengkap dan sistematis untuk memfasilitasi pembelajaran baik secara tatap muka maupun online. Penelitian ini menggunakan model pengembangan yang dikemukakan oleh Thiagarajan pada tahun 1974 yaitu define, design, develop dan disseminate. Berdasarkan hasil analisis, persentase hasil validasi yang diperoleh dari ahli materi dan evaluasi adalah $83 \%$, ahli desain $78 \%$, ahli bahasa $75 \%$, dan ahli integrasi nilai-nilai islami $79 \%$ dan uji coba kelompok kecil dengan hasil analisis $86 \%$. Berdasarkan analisis yang telah dilakukan, modul materi virus terintegrasi nilai karakter yang bersumber dari nilai keislaman berbasis E-Learning dan QR Code untuk SMA kelas X cocok untuk siswa.
\end{abstract}

Kata kunci: Module; QR Code; E-Learning; Quizizz; Nilai-Nilai Islam

\begin{abstract}
The development of this module is based on the importance of using modules for students in the learning process independently and the adaptation of the current learning process which demands to use online platforms in learning optimally. The purpose of this study was to produce a product in the form of a module development of integrated virus material based on Islamic values of E-Learning and QR Code for SMA Class $X$ which is suitable for use by students. And to overcome learning problems by developing complete and systematic teaching materials to facilitate learning both face-to-face and online. This research uses the development model suggested by Thiagarajan in 1974, namely define, design, develop and disseminate. Based on the results of the analysis, the percentage of validation results obtained from material and evaluation experts was $83 \%$, design experts $78 \%$, linguists $75 \%$, and integration experts of Islamic values $79 \%$ and small group trials with the analysis result of $86 \%$. Based on the analysis that has been carried out, the integrated virus material module of character values derived from Islamic values based on E-Learning and QR Code for SMA class $X$ is suitable for students.
\end{abstract}

Keywords: Module; QR Code; E-Learning; Quizizz ; Islamic values.

Article History

Received: April 29 $9^{\text {th }}, 2021$; Accepted: December 31 ${ }^{\text {st }}, 2021$; Published: December $31^{\text {st }}, 2021$

Corresponding Author*

Hafis M Kaunang Ataji, Universitas Muhammadiyah Metro, E-mail: hafishafisan@gmail.com

(C) 2021 Bioedusiana. This is an open access article under the CC BY-SA 4.0 license

(https://creativecommons.org/licenses/by-sa/4.0/) 


\section{PENDAHULUAN}

Dewasa ini, topik belajar pada abad ke-21 merupakan topik menarik yang telah diriset dan dikembangkan (Bellanca et al., 2010). Pembelajaran daring menggunakan fasilitas ELearning merupakan inovasi pendidikan untuk menjawab tantangan akan ketersediaan sumber belajar yang variatif (Dewi, 2020). Permasalahan pembelajaran daring bagi guru yaitu lemahnya penguasaan ilmu teknologi dan kesulitan mengawasi siswa dengan pola pembelajaran daring, bagi siswa berupa kurang aktif mengikuti proses pembelajaran, kurangnya fasilitas pendukung dan lemahnya jaringan internet, kemudian untuk orangtua belum siap untuk menjadi fasilitator proses pembelajaran.

Observasi yang telah dilakukan di SMAN 4 Metro pada September 2020 menampakkan kasus yang sama, kepada salah satu Guru Biologi kelas X bahwa saat pembelajaran pandemi Virus Covid-19 Guru menyampaikan pembelajaran menggunakan platform Google Classroom, Google Formulir dan WhatsApp. Fakta yang ditemukan saat kegiatan observasi bahwa baik sekolah, guru dan peneliti lain belum pernah mengembangkan modul materi virus dengan terintegrasi nilai-nilai Islam berbasis E-Learning dan $Q R$ Code. Pihak Guru mengakui bahwa selama adaptasi pembelajaran pada masa pandemi ini guru dan murid merasa kesulitan dalam memahami platform digital yang digunakan selama proses pembelajaran secara daring, karena biologi adalah subjek yang menghadapi begitu banyak hambatan untuk dipelajari (Çimer, 2012) sehingga perlunya pengembangan bahan ajar yang lengkap memfasilitasi pembelajaran secara tatap muka dan secara daring.

Permasalahan lain dari guru terdapat keterbatasan kemampuan dalam mengembangkan media pembelajaran daring dan bagi siswa pembelajaran daring cenderung membosankan. Era revolusi industri 4.0 membuat berbagai sektor kehidupan termasuk bidang pendidikan perlu melakukan reorientasi dalam menentukan arah kebijakan pendidikan yang menuntut peningkatan kualitas individu (Sugian Noor, 2020). Permasalahan lain dari siswa adalah tidak terbiasa belajar menggunakan E-Learning pada asalnya pembelajaran secara E-Learning akan mempermudah siswa terlatih melakukan kegiatan pembelajaran berbasis online dan akan terbiasa menggunakan jaringan virtual dalam menghadapi era digital revolusi industri 4.0 (Muhfahroyin \& Susanto, 2018). Kegiatan belajar dalam jaringan dapat berjalan baik dan efektif sesuai dengan kreatifitas guru dalam memberikan materi dan soal latihan kepada siswa dan siswa dapat mengerjakan soal latihan dengan waktu yang fleksibel (Dewi, 2020). Proses pembelajaran secara daring di SMAN 4 Metro mengakibatkan tidak fokusnya siswa dalam mengerjakan tugas sekolah, guru menyampaikan masih banyak siswa yang tidak mengerjakan tugas dikarenakan kesulitan mengakses web tugas dan tidak terpantau secara intens oleh guru. Hasil ini dapat teratasi dengan penelitian yang pelaksanaannya menggunakan Quizizz , 
ditemukan bahwa semua siswa sangat aktif menjawab pertanyaan-pertanyaan yang diberikan oleh peneliti, dan lebih berkonsentrasi pada topik (Mei et al., 2018).

Permasalahan yang diperoleh dari hasil observasi yaitu rendahnya karakter islami dari siswa, karena Minimnya karakter islami siswa menjadi tanggungjawab besar guru dalam membangun generasi muda (Khoiri et al., 2017). Modul terintegrasi Islam merupakan salah satu pilihan sumber belajar yang tepat bagi siswa pada masa sekarang ini, karena penguatan ayat AlQuran dan Hadis dalam proses pembelajaran mampu menumbuhkan keimanan dan ketaqwaan siswa (Maulidatul et al., 2020). Konsep IPTEK dalam Alquran juga dapat diterapkan dan relevan untuk diterapkan dalam proses pembelajaran di lembaga pendidikan (Fakhri, 2010). Dalam implementasinya, mengintegrasikan nilai-nilai pendidikan Islam tidaklah mudah. Keterbatasan materi dan pengalaman mungkin menjadi faktor utama yang membuat tugas ini lebih sulit (Wijayanto, 2020). Tetapi Dengan integrasi pendidikan Islam dengan IPTEK diharapkan pembelajaran menjadi lebih bermakna dan mudah dipahami (Ari Nugroho, 2017). Ibnu khuldun merujuk pentingnya menanamkan pendidikan Al-Qur'an kepada anak-anak ini. Menurutnya Al-Qur'an merupakan pondasi seluruh kurikulum pendidikan di dunia islam (Anggoro \& Haka, 2019). Pemilihan materi virus pada penelitian ini didasarkan tersebarnya COVID-19 dan berakibat pada perbedaan pola pembelajaran di Indonesia dari pembelajaran secara tatap muka menuju ke pembelajaran secara daring, hal ini sekaligus untuk mengedukasi siswa tentang virus diantaranya kemampuan virus untuk hidup yang merupakan suatu nukleoprotein yang dapat memperbanyak diri hanya dalam sel yang hidup dan memiliki kemampuan menyebabkan penyakit.

Penelitian pengembangan ini memudahkan proses pembelajaran jarak jauh yaitu proses pembelajaran yang sebagian besar waktunya digunakan di rumah. Kombinasi efektif yang ditawarkan yaitu modul pembelajaran yang dapat diaplikasikan dalam proses pembelajaran tatap muka dengan platform E-Learning Quizizz yang terinput di dalam modul melalui link QR Code yang akan banyak digunakan di rumah, sehingga proses pembelajaran akan tetap berjalan secara baik. Integrasi nilai-nilai Islam dalam pembelajaran bertujuan untuk mengarahkan peserta didik dalam ruang lingkup pendidikan yang berasaskan ketuhanan yang Maha Esa, bermoral dan berbudi pekerti luhur. Modul dalam penelitian ini memiliki ciri khas yaitu kombinasi antara pembelajaran menggunakan cetakan modul dengan pembelajaran dalam jaringan (daring) yang keduanya saling terkoneksi. Tujuan pengembangan dalam penelitian yaitu pengembangan modul materi virus terintegrasi nilai-nilai islam berbasis E-Learning dan $Q R$ Code untuk SMA Kelas X yang valid digunakan oleh siswa. Serta untuk mengatasi permasalahan pembelajaran dengan mengembangkan bahan ajar yang lengkap dan sistematis untuk memfasilitasi pembelajaran baik secara tatap muka maupun secara daring. Sedangkan tujuan penelitian ini adalah untuk menguji kelayakan modul yang dikembangkan melalui penilaian angket oleh para 
ahli dan peserta didik, sehingga modul yang dikembangkan dapat didistribusikan ke masyarakat luas dalam ranah dunia pendidikan.

\section{METODE}

Metode penelitian yang menjadi pedoman dalam penelitian ini adalah model pengembangan perangkat yang disarankan oleh (Thiagarajan et al., 1974) adalah model 4-D, model ini terdiri dari 4 tahap pengembangan, yaitu define, design, develop, dan disseminate (Gorbi Irawan et al., 2018). Namun penelitian dan pengembangan ini baru dilakukan sampai pada tahap pengembangan (baru dilakukan sampai pada tahap pengembangan atau develop).

Data penelitian ini terdiri dari data kuantitatif dan kualitatif. Data kualitatif berupa perintah, saran, dan pendapat ahli materi, ahli media, ahli integrasi, dan praktisi lapangan terhadap media pembelajaran. Data kuantitatif diperoleh dari skor validitas yang diperoleh dari masing-masing pakar melalui angket validitas. Peneliti memvalidasi kuesioner kepada supervisor yang ahli di bidangnya masing-masing sebelum memvalidasi produk. Angket yang digunakan terdiri dalam 4 jenis yaitu angket oleh ahli desain, angket validasi integrasi nilai-nilai Islam, angket ahli materi dan angket tingkat keterbacaan oleh siswa.

Kuesioner validitas dihitung dengan menggunakan skala. Pedoman penggunaan skala Pilihan Alternatif Responden dapat dilihat melalui Tabel 1.

Tabel 1. Skala Pilihan Alternatif Responden

\begin{tabular}{lc}
\hline Informasi Responden & Penilaian Skor \\
\hline Sangat Baik & 4 \\
Baik & 3 \\
Tidak Baik & 2 \\
Sangat Tidak Baik & 1
\end{tabular}

(Sumber: Zainal \& Zuhrie, 2016)

Hasil hitungan dengan menggunakan rumus di atas kemudian digunakan untuk menafsirkan kelayakan modul yang didapat secara keseluruhan, maka langkah berikutnya adalah melihat kriteria persentase skor pada Tabel 2. berikut ini.

Tabel 2. Kriteria Persentase Angket

\begin{tabular}{lll}
\hline Level Pencapaian & Kualifikasi & Keterangan \\
\hline $85 \%-100 \%$ & Sangat Baik & Tidak Perlu Direvisi \\
$75 \%-84 \%$ & Baik & Tidak Perlu Direvisi \\
$65 \%-74 \%$ & Cukup Baik & Perlu Direvisi \\
$55 \%-64 \%$ & Tidak Baik & Perlu Direvisi \\
$0 \%-54 \%$ & Sangat Tidak Baik & Perlu Direvisi \\
\hline
\end{tabular}

(Sumber: Ramlan et al., 2013) 


\section{HASIL DAN PEMBAHASAN}

Hasil dan pembahasan terkait penelitian akan dijelaskan sebagai berikut:

\section{Hasil}

\section{Define}

Menurut (Ainul et al., 2019) mengemukakan bahwa tahap ini bertujuan untuk menentukan dan mendefinisikan kebutuhan pembelajaran dengan menganalisis tujuan dan kerangka materi melalui analisis kebutuhan yang dilaksanakan di tempat penelitian. Berdasarkan hasil wawancara dengan pendidik September 2020 di SMAN 4 Metro diperoleh data sebagai berikut, 1) guru dan peneliti lain belum pernah mengembangkan modul materi virus dengan terintegrasi nilai karakter bersumber dari nilai-nilai Islam berbasis E-Learning dan $Q R$ Code. 2) Pihak Guru mengakui bahwa selama adaptasi pembelajaran dimasa pandemi ini guru dan murid merasa kesulitan dalam memahami platform digital yang digunakan selama proses pembelajaran secara daring, sehingga perlunya pengembangan bahan ajar yang lengkap memfasilitasi pembelajaran secara tatap muka dan secara daring. 3) Adaptasi proses pembelajaran saat ini menuntut kombinasi pembelajaran secara tatap muka dan daring yang maksimal, namun permasalahan yang ditemukan proses pembelajaran tatap muka yang hanya berlangsung 1-3 jam atau berangkat sekolah hanya untuk mengumpulkan tugas dan proses pembelajaran daring yang belum maksimal karena keterbatasan sosialisasi dan pemahaman platform pembelajaran oleh guru dan siswa. 4) Guru menyambut baik pengembangan bahan ajar ini, melihat tuntunan zaman dan keadaan kondisi pembelajaran saat ini menuntut untuk mengkombinasikan pembelajaran secara konvensional dan penggunaan internet secara maksimal.

\section{Design}

Tahapan design adalah tahapan untuk merancang tugas yang akan berinteraksi dengan siswa (Stephenson et al., 2020). Tahap perancangan bertujuan untuk merancang produk yang dengan desain yang disesuaikan dengan analisis kebutuhan dan kompetensi siswa. Media yang digunakan dan dikembangkan dalam penelitian ini adalah bahan ajar berupa modul. Media ini yang akan membantu siswa memahami konsep kompetensi yang dicapai. Perancangan modul berbasis E-Learning dan $Q R$ Code menjadi salah satu komponen utama dalam tahap ini, ELearning akan dimuat dalam laman web Quizizz yang akan dibantu oleh $Q R$ Code dalam mengarahkan siswa. QR Code dibuat melalui Google dengan alamat web Create $Q R$ Code.

Alamat URL yang akan dijadikan bentuk $Q R$ Code dituliskan pada lembar yang telah disediakan, selanjutnya klik menu Create $Q R$ Code lalu akan muncul dan save di penyimpanan komputer dengan nama file yang dapat disesuaikan. Modul dapat disusun dengan dua puluh komponen yang dijelaskan pada pemilihan format, kemudian E-Learning yang akan terkoneksi dengan $Q R$ Code di dalam modul yang memanfaatkan web Quizizz yang dapat menampilkan ringkasan materi dan latihan soal. 


\section{Developing}

Tahap ini merupakan tahapan pengembangan yang disusun berdasarkan analisis KI dan $\mathrm{KD}$, analisis siswa dan analisis kebutuhan proses pembuatan modul, proses pengembangan tersebut untuk kemudian berproses pada tahap validasi. Tahap pengembangan modul dapat dirinci pada Gambar 1 berikut:

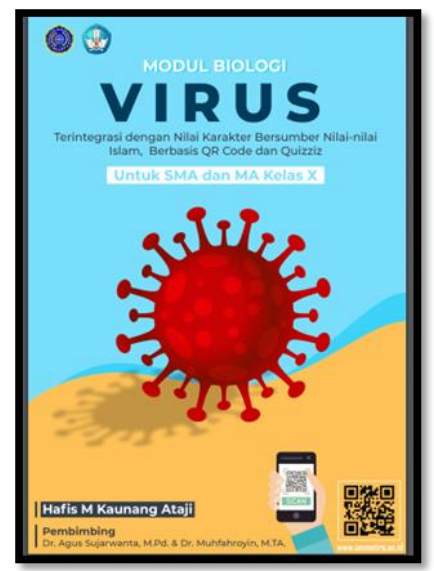

(a)

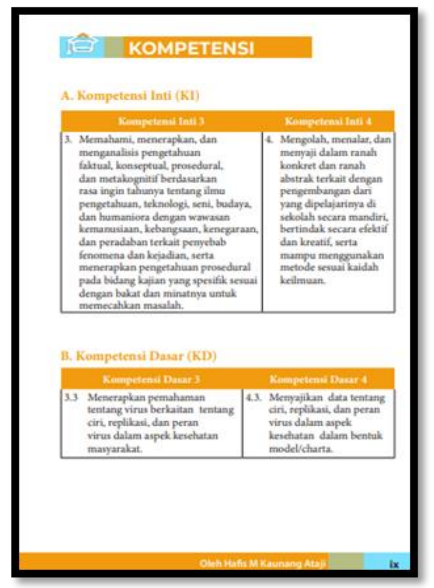

(d)

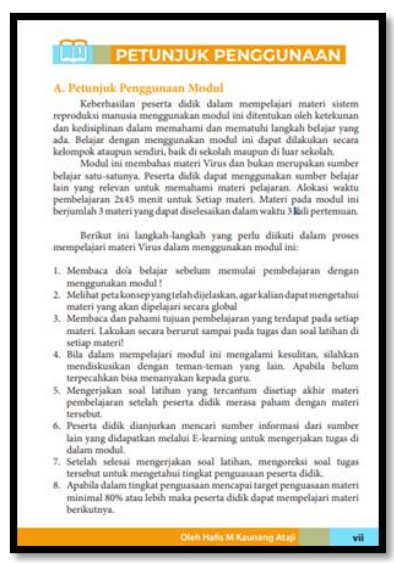

(g)

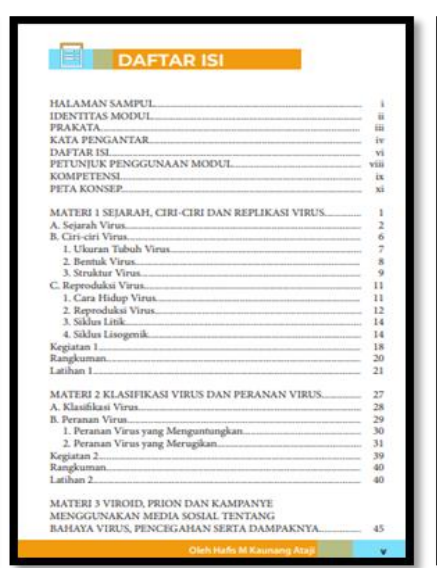

(b)

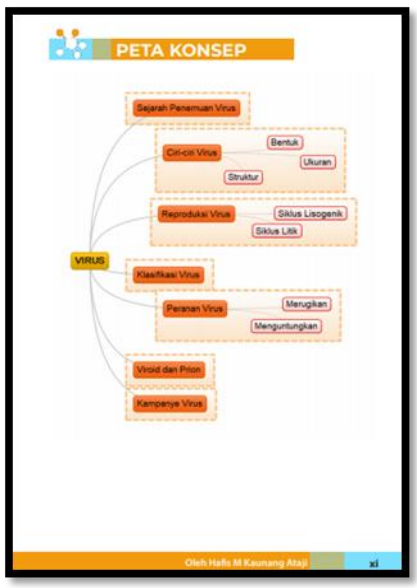

(e)

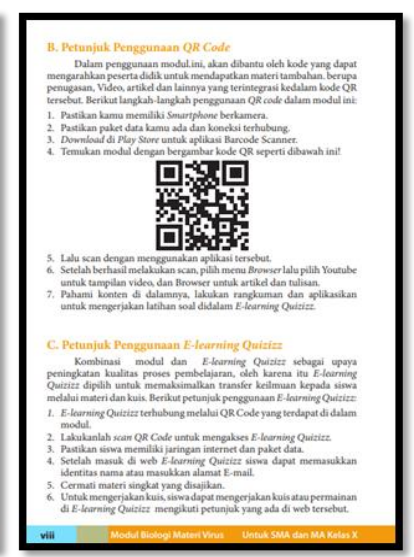

(h)

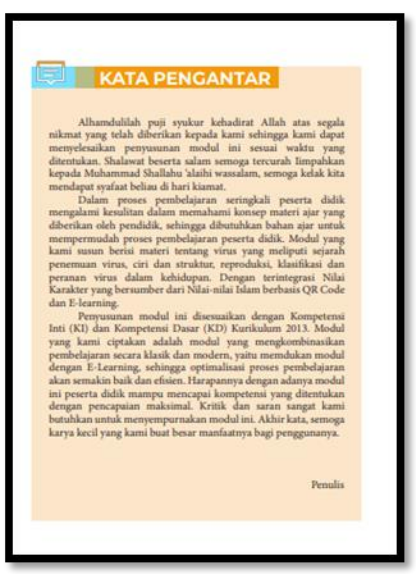

(c)

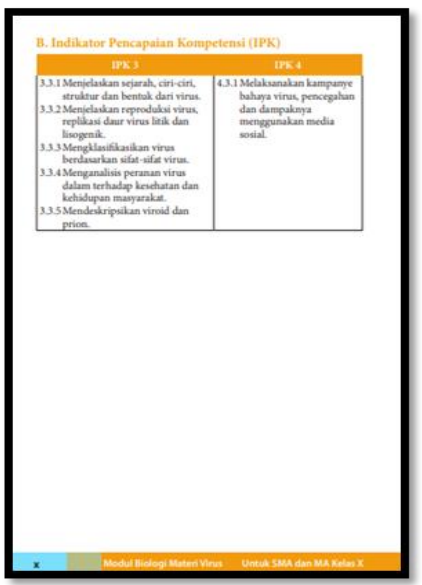

(f)

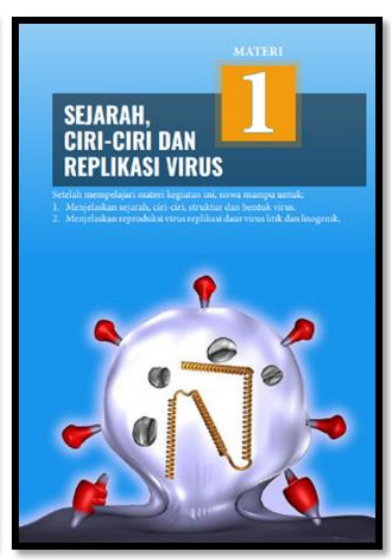

(i) 


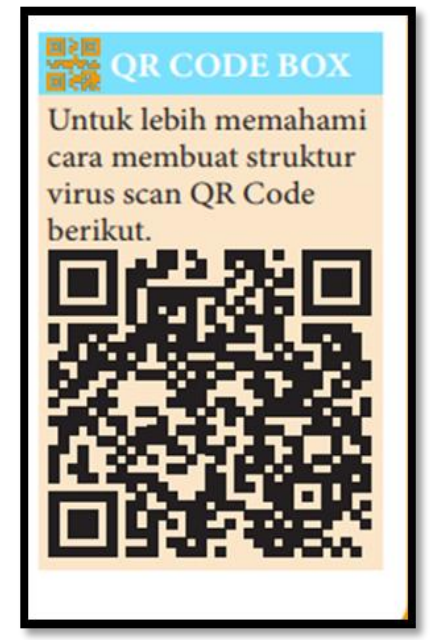

(j)

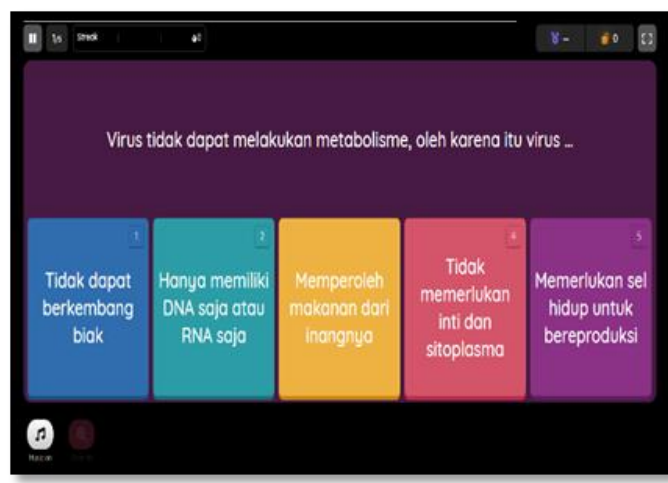

(1)

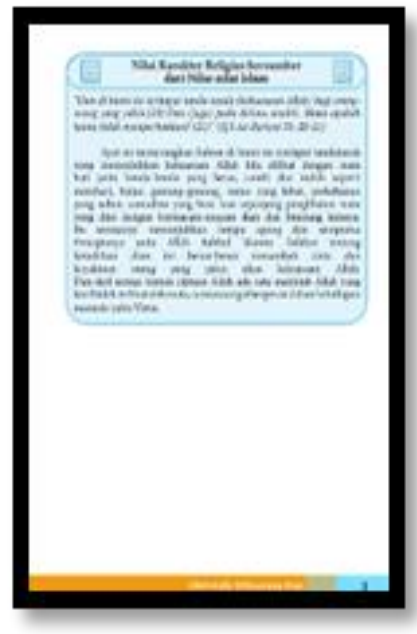

$(\mathrm{k})$

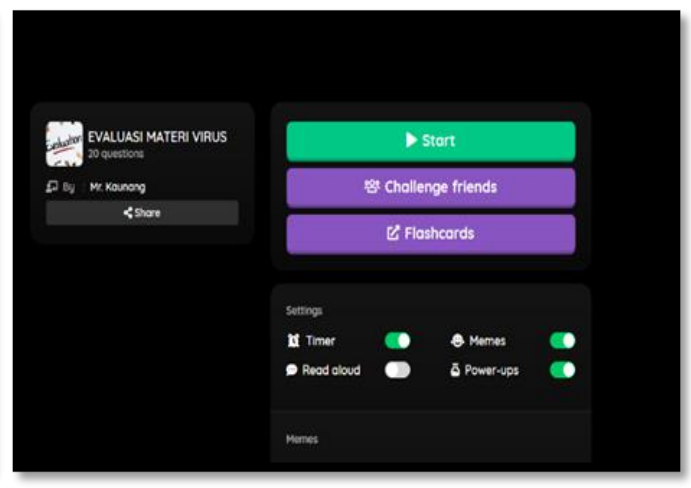

(m)

Gambar 1. Hasil dari pengembangan modul yang memiliki komponen-komponen utama yaitu; (a) Cover modul; (b) Kata Pengantar; (c) Daftar Isi; (d) Kompetensi; (e) Peta Konsep; (f) IPK; (g) Petunjuk Penggunaan Modul; (h) Petunjuk Penggunaan QR Code dan E-Learning; (i) Materi Pokok; (j) QR Code Box; (k) Integrasi Nilai Islam; (1) Evaluasi menggunakan Quizizz ; (m) Evaluasi Akhir dengan Quizizz .

Berikut merupakan sajian validasi data hasil validasi oleh ahli materi dan evaluasi pada Tabel 3.

Tabel 3. Validasi Ahli Materi dan Evaluasi

\begin{tabular}{|c|c|c|c|c|}
\hline No. & Indikator Penilaian & $\begin{array}{l}\text { Penilaian } \\
\text { Validator }\end{array}$ & $\%$ & Kategori \\
\hline 1. & $\begin{array}{l}\text { Petunjuk penggunaan modul sesuai materi } \\
\text { pembelajaran }\end{array}$ & 3 & 75 & Baik \\
\hline 2. & Tujuan pembelajaran sesuai dengan KI dan KD & 3 & 75 & Baik \\
\hline 3. & $\begin{array}{l}\text { Tujuan pembelajaran sesuai Indikator yang akan } \\
\text { dicapai. }\end{array}$ & 3 & 75 & Baik \\
\hline 4. & $\begin{array}{l}\text { Antara materi dengan tujuan pembelajaran yang } \\
\text { dicapai sudah tepat }\end{array}$ & 3 & 75 & Baik \\
\hline 5. & $\begin{array}{l}\text { Penyajian materi yang disajikan dengan KI dan KD } \\
\text { Sudah sesuai }\end{array}$ & 4 & 100 & Sangat Baik \\
\hline 6. & Latihan dan tugas & 3 & 75 & Baik \\
\hline
\end{tabular}


7. Video dengan Link $Q R$ Code dan E-Learning

8. Materi yang disajikan melalui E-Learning

9. Kesesuaian materi modul dan E-Learning dengan gambar

10. Pertanyaan soal akhir sesuai dengan materi

11. Pertanyaan soal akhir telah mencakup indikator dan tujuan pembelajaran yang akan dicapai

12. Fakta bio yang diberikan didalam modul sesuai dengan materi

Jumlah

Rata-rata

\section{4}

4

4

3

3

3

40

3.33
100

100

100

75

75

75

1000

83
Sangat Baik

Sangat Baik

Sangat Baik

Baik

Baik

Baik

Baik

Validasi ahli materi dan evaluasi didapatkan jumlah penilaian sebanyak 40 dengan ratarata hasil keseluruhan dengan 12 indikator yaitu 3.33 dengan persentase sebesar $83 \%$. Menurut (Ramlan et al., 2013) jika skor validasi yang didapat memiliki persentase sebesar 75\%-84\% dinyatakan dengan kategori baik, dengan demikian produk layak untuk diujikan kepada siswa. Selanjutnya disajikan data hasil validasi oleh ahli desain pada Tabel 4.

Tabel 4. Validasi Ahli Desain

\begin{tabular}{|c|c|c|c|c|}
\hline No. & Indikator Penilaian & $\begin{array}{l}\text { Penilaian } \\
\text { Validator }\end{array}$ & $\%$ & Kategori \\
\hline 1. & Desain sampul Modul menarik dilihat & 3 & 75 & Baik \\
\hline 2. & $\begin{array}{l}\text { Judul modul ditulis jelas, singkat dan } \\
\text { komunikatif }\end{array}$ & 3 & 75 & Baik \\
\hline 3. & Ukuran dan jenis huruf modul & 3 & 75 & Baik \\
\hline 4. & Tata letak judul modul & 3 & 75 & Baik \\
\hline 5. & $\begin{array}{l}\text { Penulisan petunjuk modul, petunjuk } \\
\text { penggunaan } Q R \text { Code dan E-Learning }\end{array}$ & 3 & 75 & Baik \\
\hline 6. & $\begin{array}{l}\text { Tujuan pembelajaran tertulis dan mudah untuk } \\
\text { dipahami }\end{array}$ & 4 & 100 & Sangat Baik \\
\hline 7. & Sistematika penulisan materi urut dan jelas & 3 & 75 & Baik \\
\hline 8. & $\begin{array}{l}\text { Pemilihan gambar mendukung materi } \\
\text { pembelajaran }\end{array}$ & 3 & 75 & Baik \\
\hline 9. & Latihan dan tugas tertulis secara sistematik & 4 & 100 & Sangat Baik \\
\hline 10 & $\begin{array}{l}\text { Tata letak penulisan Ayat dan Integrasi Nilai } \\
\text { karakter bersumber nilai-nilai Islam. }\end{array}$ & 3 & 75 & Baik \\
\hline 11. & Tata letak dan ukuran $Q R$ Code & 3 & 75 & Baik \\
\hline 12. & Kesesuaian ukuran modul dengan standar ISO & 3 & 75 & Baik \\
\hline 13. & Pemilihan dan kecerahan warna modul & 3 & 75 & Baik \\
\hline 14. & Kesesuaian letak rangkuman dan glosarium & 3 & 75 & Baik \\
\hline 15. & Kesesuaian letak latihan soal pada modul. & 3 & 75 & Baik \\
\hline & Jumlah & 47 & 1175 & \\
\hline & Rata-rata & 3.31 & 78 & Baik \\
\hline
\end{tabular}


Validasi ahli desain didapatkan jumlah penilaian sebanyak 47 dengan rata-rata hasil keseluruhan dengan 15 indikator yaitu 3.31 dengan persentase 78\% dengan kategori baik. Menurut (Ramlan et al., 2013) jika skor validasi yang didapat memiliki persentase sebesar 75\%$84 \%$ dinyatakan dengan kategori baik, dengan demikian produk layak untuk diujikan kepada siswa. Berikut merupakan penyajian data hasil validasi ahli bahasa pada Tabel 5.

Tabel 5. Validasi Ahli Bahasa

\begin{tabular}{|c|c|c|c|c|}
\hline No. & Indikator Penilaian & $\begin{array}{l}\text { Penilaian } \\
\text { Validator }\end{array}$ & $\%$ & Kategori \\
\hline 1. & Kaidah bahasa yang digunakan pada modul & 3 & 75 & Baik \\
\hline 2. & $\begin{array}{l}\text { Istilah-istilah yang digunakan sesuai dengan } \\
\text { materi virus }\end{array}$ & 3 & 75 & Baik \\
\hline 3. & Kelugasan bahasa yang digunakan & 3 & 75 & Baik \\
\hline 4. & Penggunaan bahasa komunikatif & 3 & 75 & Baik \\
\hline 5. & Ketepatan dalam menguraikan kalimat & 3 & 75 & Baik \\
\hline 6. & Ketepatan ejaan dan penulisan kata baku & 3 & 75 & Baik \\
\hline 7. & Konsistensi penulisan istilah pada modul & 3 & 75 & Baik \\
\hline 8. & $\begin{array}{l}\text { Konsistensi penggunaan simbol atau huruf } \\
\text { dalam modul }\end{array}$ & 3 & 75 & Baik \\
\hline 9. & $\begin{array}{l}\text { Penyusunan kalimat tersistem dengan } \\
\text { (PUEBI) Pedoman Umum Ejaan Bahasa } \\
\text { Indonesia }\end{array}$ & 3 & 75 & Baik \\
\hline 10. & $\begin{array}{l}\text { Kebahasaan/penggunaan kalimat pada soal } \\
\text { latihan dan Evaluasi akhir }\end{array}$ & 3 & 75 & Baik \\
\hline 11. & $\begin{array}{l}\text { Kalimat yang digunakan sederhana dan tepat } \\
\text { sasaran pada pembahasan modul }\end{array}$ & 3 & 75 & Baik \\
\hline 12. & $\begin{array}{l}\text { Kalimat dalam modul sesuai dengan } \\
\text { informasi yang dipaparkan }\end{array}$ & 3 & 75 & Baik \\
\hline & Jumlah & 36 & 900 & \\
\hline & Rata-rata & 3 & 75 & Baik \\
\hline
\end{tabular}

Validasi ahli Bahasa (Kebahasaan) oleh Dr. Achyani Subadi, M.Si didapatkan jumlah penilaian sebanyak 36 dengan rata-rata hasil keseluruhan dengan 12 indikator yaitu 3 dengan persentase 75\%. Menurut (Ramlan et al., 2013) jika skor validasi yang didapat memiliki persentase sebesar 75\%-84\% dinyatakan dengan kategori baik, dengan demikian produk layak untuk diujikan kepada siswa. Berikut merupakan data hasil validasi integrasi nilai Islam disajikan pada Tabel 6 .

Validasi ahli integrasi nilai karakter bersumber dari nilai-nilai Islam, didapatkan jumlah penilaian sebanyak 36 dengan rata-rata hasil keseluruhan dengan 11 indikator yaitu 3.27 dengan persentase 79\%. Menurut (Ramlan et al., 2013) jika skor validasi yang didapat memiliki persentase sebesar 75\%-84\% dinyatakan dengan kategori baik, dengan demikian produk layak untuk diujikan kepada siswa. Berikut merupakan grafik diagram batang yang menggambarkan 
hasil validasi. Berikut merupakan rangkuman hasil validasi oleh para ahli dalam Gambar 2. Diagram batang hasil validasi.

Tabel 6. Validasi Ahli Integrasi Nilai Islam

\begin{tabular}{|c|c|c|c|c|}
\hline No. & Indikator Penilaian & $\begin{array}{l}\text { Penilaian } \\
\text { Validator }\end{array}$ & $\%$ & Kategori \\
\hline 1. & $\begin{array}{l}\text { Kesesuaian ayat Alquran atau Hadis yang } \\
\text { diintegrasikan }\end{array}$ & 4 & 100 & Sangat Baik \\
\hline 2. & $\begin{array}{l}\text { Kesesuaian ayat Alquran dan Hadis } \\
\text { dengan materi Virus. }\end{array}$ & 3 & 75 & Bak \\
\hline 3. & $\begin{array}{l}\text { Terdapat hubungan antara Nilai Karakter } \\
\text { bersumber dari nilai-nilai Islam dengan } \\
\text { materi Virus }\end{array}$ & 3 & 75 & Baik \\
\hline 4. & $\begin{array}{l}\text { Pengintegrasian Nilai Karakter bersumber } \\
\text { dari nilai-nilai Islam berpotensi } \\
\text { meningkatkan keimanan siswa }\end{array}$ & 3 & 75 & Baik \\
\hline 5. & $\begin{array}{l}\text { Modul dapat mengajak siswa untuk belajar } \\
\text { bersyukur dan berfikir akan keagungan } \\
\text { Allah Subhanahuwata'ala }\end{array}$ & 3 & 75 & Baik \\
\hline 6. & $\begin{array}{l}\text { Materi pada modul yang diberikan } \\
\text { menunjukkan keilmuan terintegrasi kepada } \\
\text { Nilai Karakter bersumber dari nilai-nilai } \\
\text { Islam }\end{array}$ & 3 & 75 & Baik \\
\hline 7. & $\begin{array}{l}\text { Penulisan ayat Alquran atau Hadis } \\
\text { menggunakan harakat yang sesuai }\end{array}$ & 3 & 75 & Baik \\
\hline 8. & Keakuratan Penulisan terjemahan & 4 & 100 & Sangat Baik \\
\hline 9. & $\begin{array}{l}\text { Keakuratan penulisan tafsir ayat Alquran } \\
\text { atau Hadis }\end{array}$ & 3 & 75 & Baik \\
\hline 10. & $\begin{array}{l}\text { Penggunaan bahasa dan kalimat refleksi } \\
\text { Nilai Karakter bersumber dari nilai-nilai } \\
\text { Islam }\end{array}$ & 3 & 75 & Baik \\
\hline 11. & $\begin{array}{l}\text { Pengintegrasian Nilai-nilai Islam mampu } \\
\text { meningkatkan perilaku hidup bersih dan } \\
\text { sehat. }\end{array}$ & 3 & 75 & Baik \\
\hline & Jumlah & 36 & 875 & \\
\hline & Rata-rata & 3.27 & 79 & Baik \\
\hline
\end{tabular}




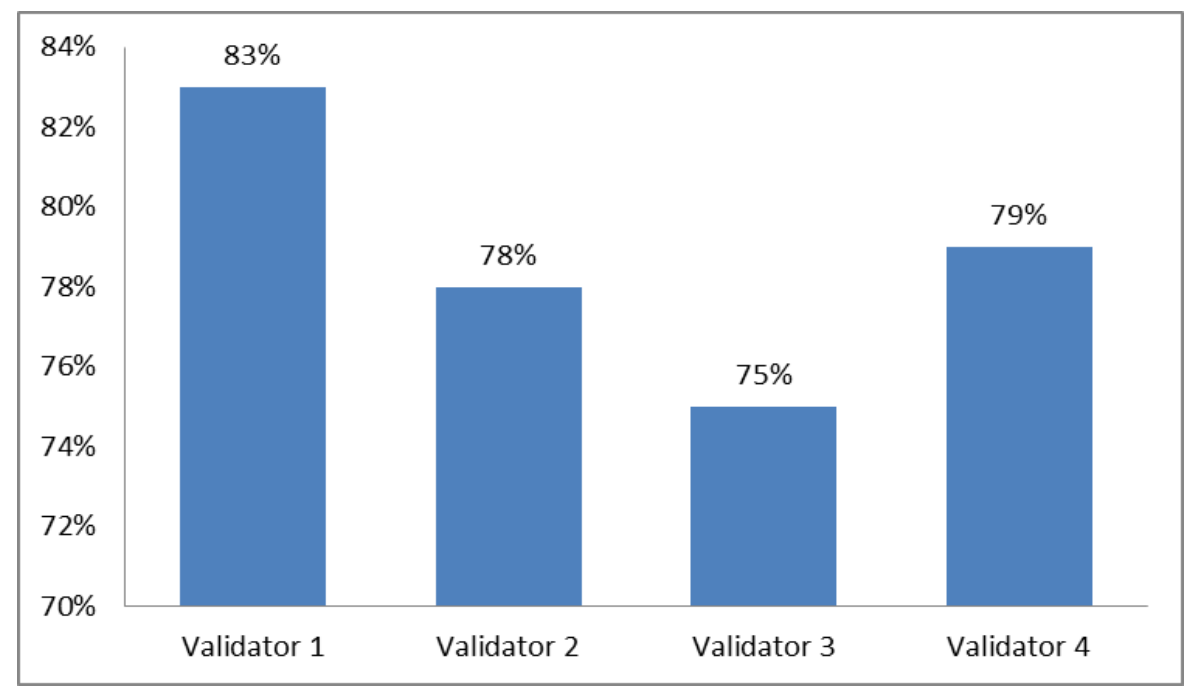

Keterangan:

Gambar 2. Diagram Batang Hasil Validasi Ahli

Validator 1 (Validasi ahli materi dan evaluasi)

Validator 2 (Validasi ahli desain)

Validator 3 (Validasi ahli bahasa)

Validator 4 (Validasi ahli integrasi nilai Islam)

Uji kelayakan modul melibatkan siswa dalam angket keterbacaan oleh siswa yang dijelaskan pada Tabel 7.

Tabel 7. Hasil Uji Coba Siswa

No. Indikator Penilaian

$\begin{array}{lll}\text { Rata- } & \% & \text { Kategori } \\ \text { rata } & \end{array}$

\begin{tabular}{|c|c|c|c|c|}
\hline 1. & Petunjuk pada modul dan E-Learning & 3.25 & 81 & Baik \\
\hline 2. & Petunjuk penggunaan $Q R$ Code & 3.35 & 83 & Baik \\
\hline 3. & $\begin{array}{l}\text { Indikator pencapaian pembelajaran tertulis point } \\
\text { per point }\end{array}$ & 3.20 & 80 & Baik \\
\hline 4. & Penggunaan bahasa mudah dipahami & 3.45 & 86 & Sangat Baik \\
\hline 5. & Pemilihan Warna modul & 3.35 & 84 & Baik \\
\hline 6. & Font huruf yang digunakan mudah terbaca & 3.50 & 87 & Sangat Baik \\
\hline 7. & Terdapat gambar-gambar yang mendukung materi & 3.50 & 87 & Sangat Baik \\
\hline 8. & $\begin{array}{l}\text { Penugasan dan latihan yang terdapat didalam } \\
\text { modul dan E-Learning }\end{array}$ & 3.55 & 89 & Sangat Baik \\
\hline 9. & $\begin{array}{l}\text { Latihan dan Tugas dalam modul dan E-Learning } \\
\text { tepat dengan materi pembelajaran }\end{array}$ & 3.60 & 90 & Sangat Baik \\
\hline 10 & Tampilan gambar terlihat menarik & 3.55 & 89 & Sangat Baik \\
\hline 11. & $\begin{array}{l}\text { Integrasi Nilai Karakter Bersumber Nilai-nilai } \\
\text { Islam mudah dipahami }\end{array}$ & 3.60 & 90 & Sangat Baik \\
\hline 12. & $\begin{array}{l}\text { Pemilihan video menggunakan } Q R \text { Code mudah } \\
\text { dipahami }\end{array}$ & 3.40 & 85 & Sangat Baik \\
\hline
\end{tabular}


13. Tampilan modul dan E-Learning secara keseluruhan terlihat menarik sehingga mempermudah proses pembelajaran

14. Tampilan materi dan Evaluasi E-Learning Quizizz mudah digunakan dan menarik

Jumlah

Rata-rata
3.50

86

Sangat Baik

48,05

3,44

87

Sangat Baik

Sangat Baik

Sangat Baik

Berdasarkan Tabel 7. menunjukkan skor rata-rata hasil uji coba siswa dengan responden berjumlah 20 siswa didapatkan nilai sebesar 3,44 dan dengan persentase sebesar 86 dengan kategori sangat baik. Menurut (Ramlan et al., 2013) jika skor validasi yang didapat memiliki persentase sebesar $85 \%-100 \%$ dinyatakan dengan kriteria sangat baik. Hal tersebut mendeskripsikan bahwa produk berupa modul yang telah dikembangkan sudah sangat baik dan layak berdasarkan angket keterbacaan yang diisi oleh siswa, sehingga layak untuk digunakan dalam proses pembelajaran.

\section{Pembahasan}

Produk yang dihasilkan yaitu modul pembelajaran dengan materi virus untuk siswa kelas X SMA. Modul ini dirancang dengan mengedepankan desain yang menarik, dan memudahkan siswa dalam pembelajaran secara mandiri, kedudukan desain dalam pengembangan modul adalah sebagai salah satu dari komponen prinsip pengembangan yang mendasari memberi arah teknik dan tahapan penyusunan modul, hal ini menunjukkan desain modul penting untuk diperhatikan karena menjadi komponen prinsip pengembangan.

Quizizz merupakan sebuah web tool untuk membuat permainan kuis interaktif untuk digunakan dalam pembelajaran di kelas anda misalnya saja untuk penilaian formatif (Sugian Noor, 2020). Pemanfaatan Quizizz membantu pendidik dalam melakukan evaluasi tanpa dibatasi tempat, tampilan yang menarik dan pengaturan waktu yang diatur sesuai dengan kesepakatan kelas (Purba, 2019). Aplikasi Quizizz dapat meningkatkan indikator menganalisis oleh siswa, selama proses pembelajaran siswa menjadi lebih aktif, meningkatkan interaksi antar siswa maupun guru, diskusi secara online dan menyampaikan pendapat (Darisman et al., 2020).

Penelitian ini penting untuk dilanjutkan karena guru belum mengembangkan bahan ajar berupa modul dengan kombinasi bersama plattform E-Learning. Pembelajaran era sekarang yang menuntut siswa untuk belajar secara mandiri dan terkonsep oleh karena itu modul penting untuk menjadi saran proses pembelajaran secara mandiri karena modul pembelajaran merupakan bahan ajar yang memiliki kelengkapan dan tersusun secara sistematis sehingga menunjang proses pembelajaran oleh siswa, sehingga dapat memahami materi secara mandiri sehingga meminimalkan bantuan dari orang lain. Modul memiliki keunggulan dibandingkan bahan ajar 
lainnya. Keunggulan modul dapat dilihat dari kelengkapan isinya. Modul berisi langkah pembelajaran lengkap (Khairani \& Nasution, 2020). Pengembangan bahan ajar modul juga harus mempertimbangkan potensi siswa, tingkat perkembangan siswa, perkembangan dunia, relevansi dengan kebutuhan siswa (Wulandari \& Agil, 2016).

Kombinasi antara modul dan Quizizz diharapkan mampu meningkatkan kualitas pembelajaran dengan adanya perpaduan antara visualisasi gambar melalui Quizizz dan konsep pembelajaran ada pada modul. Hal ini searah dengan penelitian (Çimer, 2012) yang menyimpulkan untuk peningkatan kualitas pembelajaran biologi, dengan menggunakan teknik visualisasi seperti materi 3D, objek kehidupan nyata, video, atau teknologi siswa memahami materi konsep biologi abstrak atau tak kasat mata. Pemilihan modul sebagai bahan ajar yang dikembangkan dan diterapkan dalam pembelajaran biologi karena modul memiliki karakteristik adaptif, mandiri, berdasarkan instruksi diri sendiri, dan penggunaannya yang user friendly yang menjadi keunggulan modul dibandingkan bahan ajar lain. (Ataji et al., 2019). Modul merupakan bahan ajar sesuai dengan kebutuhan pembelajaran dengan kurikulum 2013, yaitu dalam proses pembelajaran terkonsentrasi pada keaktifan dan kemampuan konstruksi ilmu oleh siswa yang mencakup pada aspek kognitif, aspek psikomotor dan afektif (Novitasari et al., 2016).

Materi pembelajaran yang baik adalah yang menghasilkan materi pembelajaran yang menarik, memotivasi dan berteknologi canggih. Penggunaan $Q R$ Code dalam proses pembelajaran erat kaitannya dengan era masyarakat Revolusi Industri 4.0 yang memiliki ciri ketergantungan yang sangat besar dalam menggunakan teknologi informasi (Muhfahroyin \& Susanto, 2018), dengan pesatnya perkembangan teknologi informasi ini, pencipta teknologi dituntut untuk menciptakan produk teknologi yang cepat, mudah, aman dan efisien. QR Code adalah contoh produk hasil kreasi revolusi industri 4.0 yang mendukung semua akses kehidupan dimulai dari mempermudah berjalannya industri, perdagangan, dan mempercepat akses penggunaan jasa termasuk proses belajar mengajar (Law \& So, 2010).

Kode QR (Respon Cepat) adalah salah satu inovasi ini (Durak et al., 2016). QR Code digunakan untuk memfasilitasi siswa dalam mengakses platform Quizizz melalui scan. Kode Respon Cepat adalah barcode dua dimensi yang digunakan untuk menyandikan dan mendekode informasi. Kode QR dapat berisi informasi seperti teks, tautan URL, pesan SMS otomatis, atau hampir semua informasi lain yang dapat disematkan dalam kode batang dua dimensi (Rikala \& Kankaanranta, 2012). QR Code benar-benar dapat menjadi inovasi terbaik, kode tersebut menyediakan persegi yang diperlukan untuk mengambil sumber daya tambahan dari alamat web. Oleh karena itu, pembelajaran yang memerlukan waktu lama dapat dengan cepat diselesaikan (So, 2011). 
Saat ini kita meyakini pergerakan penggunaan kode QR dalam pendidikan masih dalam tahap awal (Law \& So, 2010), tetapi pada beberapa penelitian guru menyatakan minat yang signifikan dalam menggunakan Sistem Pembelajaran Kode QR Terpadu untuk melakukan kegiatan pendidikan luar ruangan. Mereka juga menyatakan bahwa perangkat dan sistem $E$ Learning yang dikembangkan dalam penelitian mencapai hasil pembelajaran yang direncanakan, kemudian memberikan kesempatan interaksi secara langsung dan memfasilitasi pengajaran di berbagai lokasi (Lai et al., 2013). Quick Response (QR) Code telah dibahas dalam literatur sebagai nilai tambah dalam proses belajar mengajar. Terlepas dari potensinya dalam pendidikan, diperlukan lebih banyak penelitian untuk menginformasikan praktik dan memajukan pengetahuan di bidang ini (Ali et al., 2017). (Abdullah et al., 2014) menggunakan $Q R$ Code dalam penelitian ini bertujuan bagi guru untuk dapat membuat kode $Q R$ secara individu kemudian mengirim kode kepada siswa yang berisi link ke tujuan pembelajaran kelas, prospek perilaku dan informasi relevan lainnya.

Pembelajaran dengan E-Learning dapat dikombinasikan dengan berbagai macam model pembelajaran, dengan mengkombinasikan modul dengan Quizizz diharapkan akan semakin meningkatkan kualitas pembelajaran dan sebagai implementasi pembelajaran di era revolusi industri 4.0. Quizizz yang berperan dalam mengoptimalkan proses evaluasi dengan memberikan tampilan evaluasi yang segar dan menyenangkan (Mei et al., 2018). Siswa diharapkan lebih tertarik dan menikmati proses evaluasi yang diberikan di dalam modul dan Quizizz juga dapat menampilkan materi ringkas yang disajikan seperti slide PowerPoint akan menambah kekayaan intelektual setiap siswa (Sugian Noor, 2020).

Modul ini terintegrasi nilai karakter bersumber dari nilai-nilai Islam yang mencakup Alquran dan Hadis dapat menjadikan seorang pelajar yang baik akhlaknya dan semakin mengenal tuhannya yaitu Allah. Pendidikan Islam merupakan metode sempurna dalam usaha menciptakan generasi bertauhid dan berkarakter mulia (Wijayanto, 2020). Metode pendidikan dengan menanamkan karakter Islami dinilai yang paling baik dalam melahirkan generasi penerus bangsa yang berbudi pekerti luhur dan berakhlak mulia. Indikator pencapaian kompetensi atau IPK mengenai materi virus tertulis bahwa setelah mempelajari virus dengan modul ini siswa dapat memahami keteraturan dan kebesaran ciptaan Tuhan yang Maha Esa dengan menelaah ayat Alquran dan Hadis dalam Nilai-nilai Islam. Modul tersebut memiliki nilai karakter religius yaitu nilai kejujuran, nilai disiplin, nilai peduli lingkungan dan kesehatan, dan berbakti kepada orangtua. Dalam hal mengaitkan ayat Alquran dan Hadis dalam materi pembelajaran, peneliti melakukan pengumpulan data ayat Alquran dan Hadis bersama ahli validasi Integrasi nilai-nilai Islam. 


\section{SIMPULAN}

Pengembangan modul materi virus terintegrasi nilai-nilai Islam berbasis E-Learning dan QR Code dinyatakan valid dan layak berdasarkan validasi penyajian kriteria yang diberikan oleh ahli materi dan evaluasi, ahli desain, ahli bahasa (kebahasaan) dan ahli integrasi nilai-nilai Islam dan dapat mengatasi permasalahan pembelajaran dengan mengembangkan bahan ajar yang lengkap dan sistematis untuk memfasilitasi pembelajaran baik secara tatap muka maupun secara daring.

\section{UCAPAN TERIMA KASIH}

Kami sangat berterima kasih kepada Dr. Agus Sutanto, M.Si., Triana Asih, M.Pd., Dr. Achyani Subadi, M.Si., dan Dr. Handoko Santoso, M.Pd., sebagai validator ahli. Kami juga berterima kasih kepada guru biologi Lilik, S.Pd dari SMAN 4 Metro Lampung yang telah memberikan kesempatan untuk menggunakan kelasnya sebagai obyek penelitian; serta siswa kelas X IPA 4 SMAN4 Metro atas tanggapannya.

\section{REFERENSI}

Abdullah, A. M., Hikmat, R., \& Aziz, H. (2014). Evaluating the Use of Quick Response ( QR ) Code at Sulaimani University International Journal of Advanced Research in Evaluating the Use of Quick Response ( $Q R)$ Code at Sulaimani University Libraries. November. https://www.researchgate.net/profile/Ako-

Abdullah/publication/270879583 Evaluating the Use of Quick Response QR Code at Sulaimani_University_Libraries/links/54b66be40cf24eb34f6d193a/Evaluating-the-Use-ofQuick-Response-OR-Code-at-Sulaimani-University-Libr

Ainul, M. H., Sahat, S., \& Zul, A. (2019). Development of Learning Devices Based on Realistic Mathematics Education to Improve Students' Spatial Ability and Motivation. International Electronic Journal of Mathematics Education, 14(2), 243-252. https://doi.org/10.29333/iejme/5729

Ali, N., Santos, I. M., \& Areepattamannil, S. (2017). Pre-service teachers' perception of Quick Response (Qr) code integration in classroom activities. Turkish Online Journal of Educational Technology, 16(1), 93-100. $\quad$ https://www.researchgate.net/profile/NaglaAli/publication/312070662 Pre-

service Teachers' Perception of Quick Response QR Code integration in Classroom Activities/links/59dde35b0f7e9b53c1b26e23/Pre-service-Teachers-Perception-of-Quick-

Response-QR-Code-in

Anggoro, B. S., \& Haka, N. B. (2019). Biodik: Jurnal Ilmiah Pendidikan Biologi The

Development of Al- Qur' an Hadith based on Biology Subject for Class X Student High 
Scholl / MA Level Pengembangan Majalah Biologi Berbasis Al-Qur' an Hadist Pada Mata Pelajaran Received : 20 February 2019 R. Jurnal Ilmiah Pendidikan Biologi, 5(2), 164-172. https://core.ac.uk/download/pdf/229102529.pdf

Ari Nugroho, B. T. (2017). Integration of Islamic education with science and technology in Islamic junior high school. MUDARRISA: Jurnal Kajian Pendidikan Islam, 9(1), 1-27. https://doi.org/10.18326/mdr.v9i1.1-27

Ataji, H. K., Lepiyanto, A., \& Sutanto, A. (2019). Pengembangan Modul Berbasis QR Code Technology pada Materi Sistem Reproduksi Manusia dengan Terintegrasi Kepada A1quran dan Hadits sebagai Sumber Belajar Biologi Kelas XI Sman 1 Punggur. Bioedusiana, 4(2), 17-24. https://doi.org/10.34289/285231

Basri, A. H. H. (2015). Bioekologi Virus Mosaik Bergaris Tebu (Sugarcane Streak Mosaic Virus) Dan Cara Pengendalian. Agrica Ekstensia, 9(1), 50-57. https://www.polbangtanmedan.ac.id/pdf/Jurnal 2015/Vol 9 No 1/07 Arie Hapsani.pdf Bellanca, J., Eds, R. B., Barell, J., Darling-hammond, L., Dede, C., Dufour, R., Dufour, R., Fisher, D., Fogarty, R., Frey, N., Gardner, H., Hargreaves, A., David, W., Johnson, R. T., Kay, K., Lemke, C., Mctighe, J., \& November, A. (2010). 21C 21st Century Skills: Rethinking How Students Learn. Solution Tree Press Study Guide, Study Guide, 1-27. http://www.edugains.ca/resources21CL/Research/Readings/21stCenturySkills ReThinkingHowStudentsLearn.pdf

Çimer, A. (2012). What Makes Biology Learning Difficult and Effective: Students' Views. Educational Research and Reviews, 7(3), 61-71. https://doi.org/10.5897/ERR11.205

Darisman, A. I. M., Suprapto, P. K., \& Putra, R. R. (2020). Implementasi Aplikasi Quizizz Pada Materi Jaringan Tumbuhan. Florea: Jurnal Biologi Dan Pembelajarannya, 7(2), 68. https://doi.org/10.25273/florea.v7i2.5297

Dewi, W. A. F. (2020). Dampak COVID-19 terhadap Implementasi Pembelajaran Daring di Sekolah Dasar. Edukatif: Jurnal Ilmu Pendidikan, 2(1), 55-61. https://doi.org/10.31004/edukatif.v2i1.89

Durak, G., Ozkeskin, E. E., \& Ataizi, M. (2016). QR Codes in education and communication. Turkish Online Journal of Distance Education, 17(2), 42-58. https://doi.org/10.17718/tojde.89156

Fakhri, J. (2010). Sains Dan Teknologi Dalam Al-Qur'an Dan Implikasinya Dalam Pembelajaran. Ta'dib:Journal of Islamic Education (Jurnal Pendidikan Islam), 15(01), 121-142. https://doi.org/10.19109/tjie.v15i01.70

Gorbi Irawan, A., nyoman Padmadewi, N., \& Putu Artini, L. (2018). Instructional materials development through 4D model. SHS Web of Conferences, 42, 00086. https://doi.org/10.1051/shsconf/20184200086 
Hussain, S. B. S., Kuswiyanto, R. B., \& Iwan, J. (2016). Electrocardiogram Profile in Children with Dengue Infection at Dr. Hasan Sadikin General Hospital and Bandung City Hospital. Althea Medical Journal, 3(4), 629-632. https://doi.org/10.15850/amj.v3n4.950

Khairani, M., \& Nasution, I. W. (2020). Analysis of Student Responses to Module Development Based on Islamic Integration in Biology Learning in Class XI. BEST Journal (Biology Education, Sains and Technology), 3(2), 257-262. https://doi.org/10.30743/best.v3i2.3303

Khoiri, A., Agussuryani, Q., \& Hartini, P. (2017). Penumbuhan Karakter Islami melalui Pembelajaran Fisika Berbasis Integrasi Sains-Islam. Tadris: Jurnal Keguruan Dan Ilmu Tarbiyah, 2(1), 19. https://doi.org/10.24042/tadris.v2i1.1735

Lai, H. C., Chang, C. Y., Wen-Shiane, L., Fan, Y. L., \& Wu, Y. T. (2013). The implementation of mobile learning in outdoor education: Application of $Q R$ Codes. British Journal of Educational Technology, 44(2), 57-62. https://doi.org/10.1111/j.1467-8535.2012.01343.x

Law, C., \& So, S. (2010). QR Codes in Education. Journal of Educational Technology Development and Exchange, 3(1). https://doi.org/10.18785/jetde.0301.07

Maulidatul, A., Ismail, I., \& Mukhlishoh, S. (2020). Pengembangan Modul Biologi Terintegrasi Nilai Islam Pada Materi Sistem Reproduksi Manusia. BIOEDUCA: Journal of Biology Education, 1(1), 17. https://doi.org/10.21580/bioeduca.v1i1.4951

Mei, S. Y., Ju, S. Y., \& Adam, Z. (2018). Implementing Quizizz as Game Based Learning in the Arabic Classroom. European Journal of Social Sciences Education and Research, 12(1), 208. https://doi.org/10.26417/ejser.v12i1.p208-212

Muhfahroyin, \& Susanto, E. (2018). The Implementation of E-Learning to Improve Students' Virtual Activities. Journal of Physics: Conference Series, 1114(1). https://doi.org/10.1088/1742-6596/1114/1/012039

Novitasari, E., Masykuri, M., \& Aminah, N. S. (2016). Pengembangan Modul Pembelajaran IPA Terpadu Berbasis Inkuiri Terbimbing Tema Matahari Sebagai Sumber Energi Alternatif di Kelas VII SMP/MTs. Jurnal Inkuiri, 5(1), 112-121. http://jurnal.fkip.uns.ac.id/index.php/inkuiri/article/view/9243

Purba, L. S. L. (2019). Peningkatan Konsentrasi Belajar Mahasiswa Melalui Pemanfaatan Evaluasi Pembelajaran Quizizz Pada Mata Kuliah Kimia Fisika I. Jurnal Dinamika Pendidikan, 12(1), 29. https://doi.org/10.33541/jdp.v12i1.1028

Ramlan, Haeruddin, \& Kamaluddin. (2013). Pengembangan Media Pembelajaran E-Materi Dengan Model Pembelajaran Bebasis Masalah. 1(2), 12-17. http://jurnal.untad.ac.id/jurnal/index.php/EPFT/article/view/2388/1683

Rikala, J., \& Kankaanranta, M. (2012). The use of Quick Response codes in the classroom. CEUR Workshop Proceedings, 955(October 2012), 148-155. http://ceur-ws.org/Vol955/papers/paper 40.pdf 
So, S. (2011). Beyond the simple codes: QR Codes in education. ASCILITE 2011 - The Australasian Society for Computers in Learning in Tertiary Education, 2010, 1157-1161. https://www.ascilite.org/conferences/hobart11/downloads/papers/So-concise.pdf

Stephenson, N. S., Duffy, E. M., Day, E. L., Padilla, K., Herrington, D. G., Cooper, M. M., \& Carmel, J. H. (2020). Development and Validation of Scientific Practices Assessment Tasks for the General Chemistry Laboratory. Journal of Chemical Education, 97(4), 884-893. https://doi.org/10.1021/acs.jchemed.9b00897

Sugian Noor. (2020). Penggunaan Quizizz Dalam Penilaian Pembelajaran Pada Materi Ruang Lingkup Biologi Untuk Meningkatkan Hasil Belajar Siswa Kelas X.6 SMA 7 Banjarmasin. Jurnal Pendidikan Hayati, $\quad 6(1), \quad 1-7$. https://www.jurnal.stkipbjm.ac.id/index.php/JPH/article/view/927

Thiagarajan, S., Semmel, D. S., \& Semmel, M. I. (1974). Instructional development for training teachers of exceptional children: A sourcebook. Journal of School Psychology, 14(1), 75. https://doi.org/10.1016/0022-4405(76)90066-2

Wijayanto, M. E. (2020). the Integration of Islamic Values in Implementation of Learning English: Islamic Education Students Perspective. ETERNAL (English, Teaching, Learning, and Research Journal), 6(1), 18. https://doi.org/10.24252/eternal.v61.2020.a2

Wulandari, H., \& Agil, L. (2016). PENGEMBANGAN MODUL PEMBELAJARAN BIOLOGI BERORIENTASI SIKLUS BELAJAR UNTUK SISWA KELAS XI SMA TELADAN 1 METRO. Bioedukasi Jurnal Pendidikan Biologi, 7(2), 129-132. https://ojs.fkip.ummetro.ac.id/index.php/biologi/article/view/614/493

Zainal, A., \& Zuhrie, M. (2016). Pengembangan Trainer Dan Jobsheet Mikrokontroler Sebagai Media Pembelajaran Pada Mata Pelajaran Perekayasaan Sistem Kontrol Di Jurusan Elektronika Industri Smk Negeri 1 Bangil. Jurnal Pendidikan Teknik Elektro, 5(1), 383-388. https://jurnalmahasiswa.unesa.ac.id/index.php/jurnal-pendidikan-teknikelektro/article/view/14057/4873 